\title{
Prevalence of Anal Fistulas in Europe: Systematic Literature Reviews and Population-Based Database Analysis
}

\author{
Damián García-Olmo (1) - Gert Van Assche (1) - Ignacio Tagarro (1) · \\ Mary Carmen Diez (1) · Marie Paule Richard (1) · Javaria Mona Khalid (1) · \\ Marc van Dijk (1) · Dimitri Bennett (D) - Suvi R. K. Hokkanen (1) · \\ Julián Panés
}

Received: August 23, 2019 / Published online: October 26, 2019

(C) The Author(s) 2019

\section{ABSTRACT}

Introduction: Despite the fact that perianal fistulas are associated with significant morbidity and impaired quality of life, their prevalence in Europe is unknown. The aim of this study was to estimate the prevalence of perianal fistulas in Europe, overall and according to etiology.

Methods: Two independent literature reviews were performed using different search strategies

Enhanced Digital Features To view enhanced digital features for this article go to https://doi.org/10.6084/ m9.figshare.9948788.

Electronic Supplementary Material The online version of this article (https://doi.org/10.1007/s12325019-01117-y) contains supplementary material, which is available to authorized users.

\section{García-Olmo $(\bowtie)$}

Hospital Universitario Fundación Jiménez Díaz, Av de los Reyes Católicos, 2, 28040 Madrid, Spain e-mail: damian.garcia@uam.es

\section{G. Van Assche}

Department of Gastroenterology and Hepatology, University Hospitals Leuven and Katholic University Leuven, Leuven, Belgium

I. Tagarro

Takeda Spain, Madrid, Spain

M. C. Diez - M. P. Richard

TiGenix (Takeda Group), Madrid, Spain

J. M. Khalid · M. van Dijk

Takeda Development Centre Europe, London, UK to maximize the identification of potentially relevant studies. Data from relevant articles were used to estimate the prevalence of perianal fistulas in Europe. The robustness of the estimate was evaluated using data from a large population-based database from the UK.

Results: A total of 26 studies provided epidemiological data on perianal fistulas, of which 16 provided suitable data to estimate the prevalence. Estimations using these data yielded a total prevalence of 1.69 per 10,000 population. Cryptoglandular infection and Crohn's disease $(\mathrm{CD})$ were the predominant etiologies, with prevalence rates at 0.86 and 0.76 per 10,000 population, respectively. Comparison of prevalence data from the UK population-based database with the European population resulted

\section{Bennett}

Department of Pharmacoepidemiology, Takeda

Pharmaceutical Company Limited, Cambridge, MA, USA

\section{Bennett}

Center for Clinical Epidemiology and Biostatistics, Adjunct, Perelman School of Medicine, University of Pennsylvania, Philadelphia, PA, USA

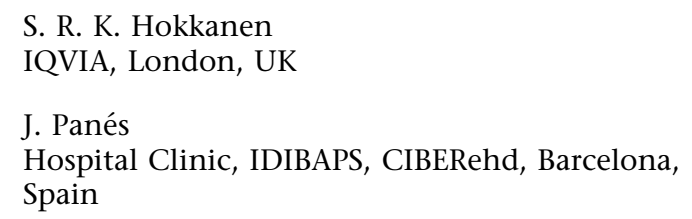


in a standardized prevalence estimate of all perianal fistulas of 1.83 per 10,000 population, confirming the robustness of the literaturebased estimate.

Conclusion: Although in terms of incidence cryptoglandular fistulas were clearly predominant, the prevalence of fistulas in $\mathrm{CD}$ and cryptoglandular infection appeared more balanced. This is due to the longer duration and higher frequency of relapses of fistulas in CD. The estimated prevalence implies that perianal fistulas meet the criteria to be considered as a rare condition in Europe (prevalence less than 5 per 10,000 population).

Funding: This study was funded by Takeda Pharmaceutical U.S.A., Inc. and TiGenix SAU.

Keywords: Anal fistula; Epidemiology; Europe; Incidence; Prevalence

\section{Key Summary Points}

Why carry out this study?

Perianal fistulas are associated with significant morbidity and impaired quality of life. However, their prevalence in Europe is unknown.

\section{What was learned from the study?}

This article describes two independent literature reviews showing a prevalence of perianal fistulas in Europe of 1.69 per 10,000 population.

Cryptoglandular infection and Crohn's disease were the predominant aetiologies, with prevalence of 0.86 and 0.76 per 10,000 population, respectively.

Analyses of a large population-based database from the UK confirmed the robustness of this estimate.

The data indicate that perianal fistulas meet the criterion to be considered a rare condition in Europe (prevalence less than 5 per 10,000 population established by the European Medicines Agency).

\section{INTRODUCTION}

Fistulas are abnormal connections between two epithelialized surfaces $[1,2]$. An external fistula is defined as one that connects an internal organ and the skin surface [3]. According to the most widely accepted definition, an anal fistula is an external fistula that creates an abnormal connection between the anorectum and perianal epithelium [4-7]. Anal fistulas are associated with significant clinical manifestations (e.g., local pain, phlogosis, purulent drainage, and incontinence) and impaired health-related quality of life [6]. Although surgery of anal fistulas is one of the most common operations performed by colorectal surgeons and new therapies for this condition make epidemiologic data relevant for heathcare planning, the prevalence of this condition remains largely unknown.

Most anal fistulas are either of cryptoglandular origin or secondary to Crohn's disease (CD), although a variety of other etiologies have been identified, including infection, trauma, cancer, and congenital malformation. Whereas cryptoglandular anal fistulas are assumed to be caused by an infection of the anal glands $[6,8]$, those related to $\mathrm{CD}$ appear to be a consequence of anorectal lesions produced by the transmural inflammatory process $[9,10]$.

The aim of the present study was to estimate the prevalence of anal fistulas in Europe overall and by etiology.

\section{METHODS}

For this study, the most common definition of anal fistula was used (abnormal connection between the anorectum and perianal skin). Other suppurating perianal/perirectal conditions are beyond the scope of this work.

\section{Literature Review}

To optimize the probability of retrieving relevant articles, two separate systematic literature searches were conducted. The first was a targeted search of the MEDLINE database, 
performed using a series of specific search terms covering the different etiologies of anal fistulas. The second employed more generic search terms, and included studies indexed in MEDLINE, Embase, and Cochrane databases. In this case, search terms referred to anal fistulas, but not to their specific etiologies. The full search algorithms are available in Supplementary Material Files 1 and 2.

The two searches, completed in December 2017, were conducted independently, and the retrieved titles and abstracts were screened by two independent reviewers. No restrictions were placed on the type of study or publication included, with selection based solely on the relevance of data reported to the study question. Eligible studies were those published in English, reporting European population-based epidemiologic data on anal fistulas, with an appropriate case definition, from which prevalence could be estimated. Potentially relevant articles were subjected to full text review and those fulfilling the aforementioned selection criteria were used to estimate the prevalence of anal fistulas.

Bibliographies of the selected articles were screened to identify any additional sources of relevant data.

For etiologies in which only incident cases were reported or could be derived, prevalence was estimated from the reported incidence and the median duration of the condition, based on the following equation relating to both variables [11]:

Point prevalence $=$ incidence $\times$ duration of condition

For etiologies leading to fistulas of 1-year duration or less, incidence was assumed to represent a conservative estimate of prevalence.

The overall prevalence of CD-related anal fistulas was calculated as the mean prevalence of anal fistulas in the Crohn's population, obtained from population-based, cross-sectional studies, multiplied by the weighted mean prevalence of CD/10,000 population in Europe, obtained from studies published over the last 10 years (2008-2017; Supplementary Material File 3) [12-31]. The weighted mean prevalence of Crohn's disease was calculated on the basis of the 2017 mid-year populations [32].

The literature review is based on previously conducted studies and does not contain any studies with human participants or animals performed by any of the authors.

While the study was not captured in a database, the PRISMA (Preferred Reporting Items for Systematic Reviews and Meta-Analyses) guidelines [33] were followed as closely as possible to ensure reporting transparency. Given the nature of the data collected, it was deemed inappropriate to attempt a meta-analysis of the extracted data, and this study is a systematic review of the literature only.

\section{Population-Based Database Analysis}

To validate the estimates derived from the literature, the prevalence of anal fistulas among patients in a population-based healthcare database in the UK was compared with the European population. This analysis employed The Health Improvement Network (THIN) [34], a primary care database containing electronic medical records for more than 3 million active patients. Relevant diagnostic and surgical codes were used to identify cases of anal fistula (Supplementary Material File 4). To account for the longer duration of anal fistulas in CD compared with non-CD etiologies, prevalence estimates were calculated using an assumed duration of at most 4 years for anal fistulas related to $C D$ and at most 12 months for etiologies other than CD, following clinical judgement and published data [35]. Anal fistulas in CD were defined as having a CD diagnosis at any time before or up to 4 years after the anal fistula diagnosis, as anal fistulas may be the first manifestation of CD. Prevalence was calculated on the basis of the numbers of prevalent cases of anal fistulas and active patients as of July 1 of each year.

To facilitate standardization to the UK and European population reference sets, prevalence estimates were stratified by age and sex. The latest population reference sets for the UK (2016) [36] and Europe (2013) [37] were then used to extrapolate prevalence estimates to the UK and European populations, respectively. 
The population-based database analysis was reviewed and approved by the THIN Scientific Review Committee (SRC 18THIN006). The study conformed to the Helsinki Declaration of 1964, as revised in 2013, and Springer's ethical policy.

\section{RESULTS}

The two literature searches yielded totals of 596 and 356 publications, of which 26 and 6, respectively, were found to provide epidemiologic data related to anal fistulas, with an overlap of six references. After full text review, 16 studies in total were found suitable to be used as data sources to estimate the prevalence of anal fistulas (Fig. 1, Table 1). Where recorded, the included cohorts were predominantly male and aged 30-50 years (Table 1) [38-53]. The ten excluded studies and the corresponding reasons for exclusion are listed in Supplementary Material File 5.

\section{Anal Fistulas of Cryptoglandular Origin}

A single article provided data suitable to derive the prevalence of anal cryptoglandular fistulas. Sainio [38] estimated the incidence among the residents of Helsinki, based on the number of patients hospitalized for surgery related to anal fistulas of cryptoglandular origin from 1969 to 1978. Although conducted in a hospital setting, the study provided a population-based perspective, as surgical intervention is the primary treatment modality in virtually all patients with this type of anal fistula. The reported annual incidence was $0.86 / 10,000$ population. Given the limited duration of the condition (on average up to 1 year according to clinical experience), the reported incidence represents an acceptable estimate of the prevalence.

\section{Crohn's Disease-Related Anal Fistulas}

The estimated prevalence of anal fistulas related to CD was based on four studies (Table 2). A Spanish group conducted a cross-sectional study in 635 consecutive outpatients from 39 randomly selected clinics and hospitals [39]. It reported perianal disease in $12.0 \%$ of patients with CD. Based on evidence suggesting that $50 \%$ of patients with CD and perianal involvement have perianal fistulas [54], the estimated prevalence of anal fistulas in CD was $6.0 \%$. Of note, these data can be considered populationbased as the vast majority of patients with $\mathrm{CD}$ in Spain are diagnosed and followed in secondary and tertiary centers.

A second Spanish study evaluated the incidence of perianal fistulas in 2391 patients with CD treated in secondary and tertiary institutions, and reported an annual incidence of $1.2 \%$ [40]. On the basis of the median duration of anal fistulas in patients with CD [35], the annual incidence reported in the present study was multiplied by a median duration of 3.6 years, resulting in an estimated prevalence of $4.3 \%$ among the CD population.

In a Dutch population-based study evaluating anal fistulas in 1162 patients with CD, Göttgens et al. [41] reported an incidence of $8.3 \%$ during the first year following initial diagnosis of $\mathrm{CD}$ and a cumulative incidence of $15.8 \%$ at 10 years after diagnosis. Analysis of the data suggested that the cumulative incidence during years 2-10 after the initial diagnosis of CD (7.5\%) was linear, yielding an annual incidence of $0.83 \%$ over this period. To estimate prevalence, annual incidence was derived from the annual incidence estimates of $8.3 \%$ during the first year after diagnosis and $0.83 \%$ during years 2-10 applied to the mean incidence and prevalence of CD (1.4/10,000 and 25.14/10,000 population, respectively; means of figures recently reported in two Dutch studies) [22, 23]. The resulting annual incidence of anal fistulas in patients with $\mathrm{CD}(0.31 / 10,000$ population) was multiplied by the median duration of the condition (3.6 years), yielding an estimated prevalence of $1.13 / 10,000$ population. Considering the aforementioned prevalence of $\mathrm{CD}$ in the Netherlands, it was concluded that the prevalence of anal fistulas in the $\mathrm{CD}$ population was $4.49 \%$.

Finally, Georgiadou et al. [42] performed a retrospective analysis of a German claims database that included 13,346 patients with CD. Among these patients, 451 had a concurrent 
A

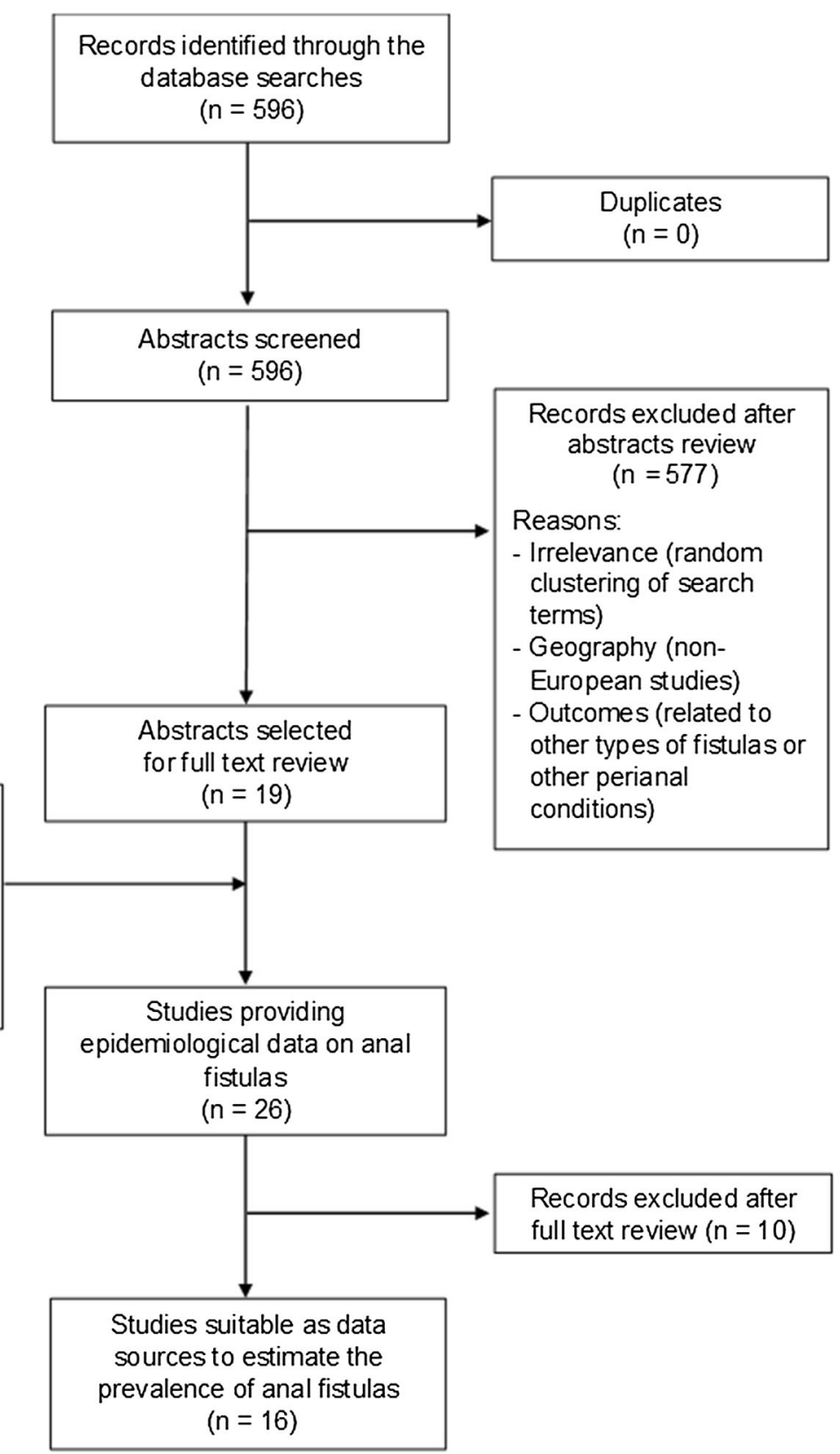

Fig. 1 Study flow diagram corresponding to the $\mathbf{a}$ targeted literature search and $\mathbf{b}$ systematic literature search

diagnosis of perianal fistula, suggesting an overall prevalence of $3.38 \%$.

The mean prevalence of anal fistulas in CD across the four studies was $4.55 \%$. Extrapolation to the European population using a weighted mean prevalence of CD of 16.63/10,000 population (Fig. 2) yielded an estimated prevalence of CD-related anal fistulas of $0.76 / 10,000$ population. Based on a median duration of
3.6 years, the estimated annual incidence of CD-related anal fistulas was $0.21 / 10,000$ population.

\section{Trauma-Induced Anal Fistulas}

Six studies provided data on the prevalence of anal fistulas related to iatrogenic trauma, all of which assessed the frequency of anal fistulas 


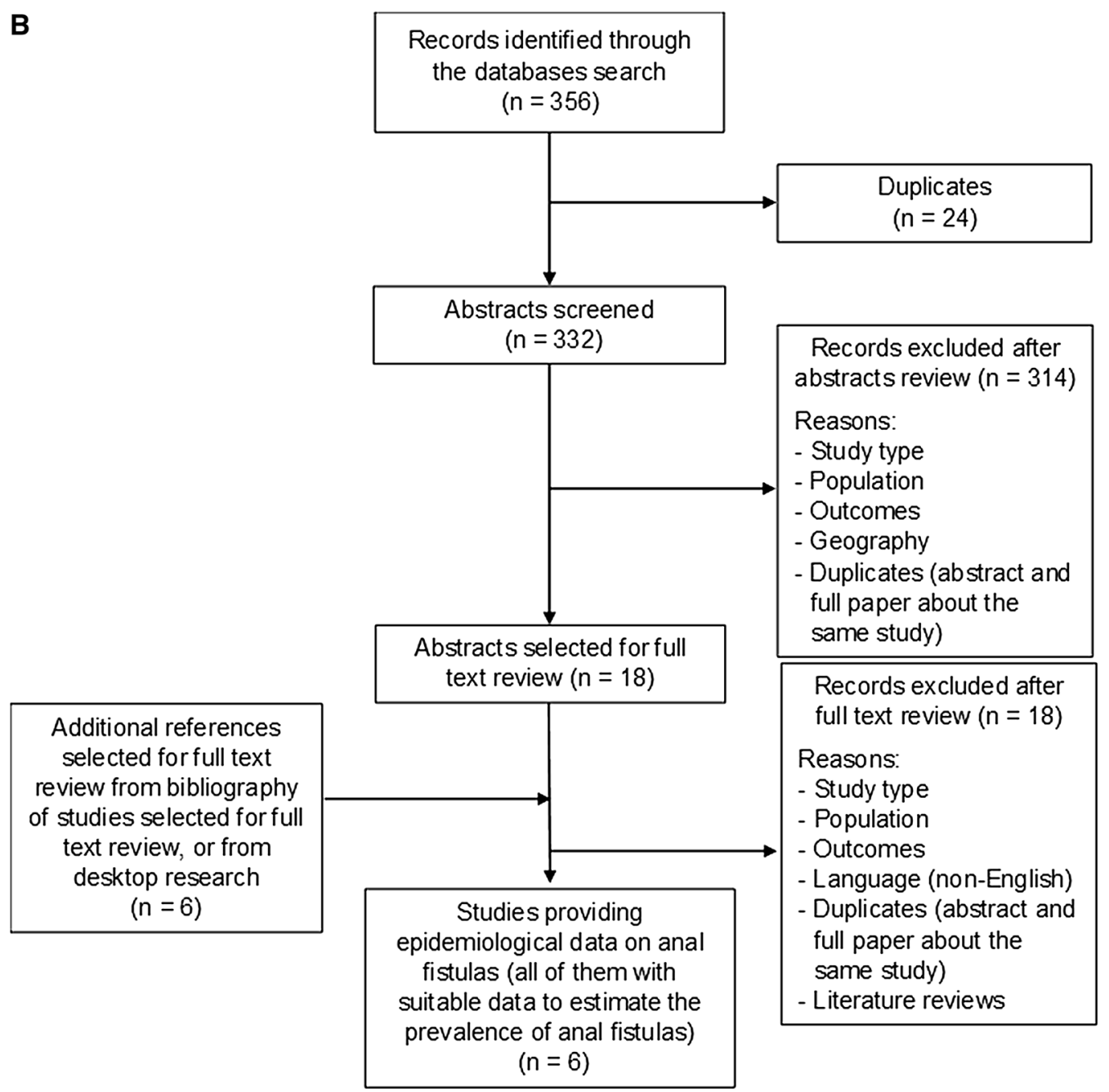

Fig. 1 continued

subsequent to hemorrhoidectomy (Table 3) [43-48].

The weighted mean frequency of anal fistulas reported as a complication of hemorrhoidectomy in the studies included in this analysis was $0.69 \%$. Based on an estimated annual frequency of 4.5 hemorrhoidectomies/10,000 population derived from studies in Germany and England $[55,56]$, the estimated incidence of post-hemorrhoidectomy anal fistulas in Europe was 0.31/ 10,000 population. Given the short duration of the condition, this incidence represents a conservative estimate of the prevalence of anal fistulas following hemorrhoidectomy.

\section{Anal Fistulas Related to Other Etiologies}

Five studies were identified with suitable data to facilitate estimation of the prevalence of anal fistulas related to other etiologies, including infection, cancer, and congenital malformation [49-53]. Table 4 summarizes the estimated prevalence of these etiologies of anal fistulas based on the studies included in this analysis.

Three studies reporting suitable data on anal fistulas related to infection were identified, including two reports on anal fistulas in patients with tuberculosis and one case series in patients with lymphogranuloma venereum [49-51]. According to the most recent estimate from the European Centre for Disease 
Table 1 Studies used as source of data in the analysis of the prevalence of anal fistulas in Europe

\begin{tabular}{|c|c|c|c|c|c|c|c|}
\hline Etiology & Study & Region & Design & $\begin{array}{l}\text { Number } \\
\text { of } \\
\text { patients } \\
\text { included }\end{array}$ & $\begin{array}{l}\text { Male } \\
(\%)\end{array}$ & $\begin{array}{l}\text { Average } \\
\text { age } \\
\text { (years) }\end{array}$ & $\begin{array}{l}\text { Estimation made from } \\
\text { the reported data }\end{array}$ \\
\hline Cryptoglandular & $\begin{array}{l}\text { Sainio } 1984 \\
{[38]}\end{array}$ & Finland & $\begin{array}{l}\text { Retrospective } \\
\text { analysis }\end{array}$ & 458 & 63 & $38^{\mathrm{a}}$ & $\begin{array}{l}\text { Prevalence of } \\
\text { cryptoglandular anal } \\
\text { fistula }\end{array}$ \\
\hline \multirow[t]{4}{*}{ Crohn's disease } & $\begin{array}{l}\text { SEESG-CD } \\
1999[39]\end{array}$ & Spain & $\begin{array}{l}\text { Cross-sectional } \\
\text { observation } \\
\text { study }\end{array}$ & 635 & 48 & 33 & $\begin{array}{l}\text { Prevalence of Crohn's- } \\
\text { related anal fistula }\end{array}$ \\
\hline & $\begin{array}{l}\text { Chaparro } \\
\text { et al. } 2011 \\
\text { [40] }\end{array}$ & Spain & $\begin{array}{l}\text { Population- } \\
\text { based cohort } \\
\text { study }\end{array}$ & 2391 & 55 & $41^{b}$ & $\begin{array}{l}\text { Prevalence of Crohn's- } \\
\text { related anal fistula }\end{array}$ \\
\hline & $\begin{array}{l}\text { Göttgens } \\
\text { et al. } 2017 \\
\text { [41] }\end{array}$ & Netherlands & $\begin{array}{l}\text { Population- } \\
\text { based cohort } \\
\text { study }\end{array}$ & 1162 & 37 & $38^{c}$ & $\begin{array}{l}\text { Prevalence of Crohn's- } \\
\text { related anal fistula }\end{array}$ \\
\hline & $\begin{array}{l}\text { Georgiadou } \\
\text { et al. } 2019 \\
\text { [42] }\end{array}$ & Germany & $\begin{array}{l}\text { Cross-sectional } \\
\text { claims } \\
\text { database } \\
\text { analysis }\end{array}$ & 13,346 & NR & NR & $\begin{array}{l}\text { Prevalence of Crohn's- } \\
\text { related anal fistula }\end{array}$ \\
\hline \multirow[t]{6}{*}{ Trauma } & $\begin{array}{l}\text { Sielezneff } \\
\text { et al. } 1997 \\
\text { [43] }\end{array}$ & France & $\begin{array}{l}\text { Retrospective } \\
\text { cohort study }\end{array}$ & 1134 & 71 & 48 & $\begin{array}{l}\text { Prevalence of trauma- } \\
\text { related anal fistula } \\
\text { (iatrogenic) }\end{array}$ \\
\hline & $\begin{array}{l}\text { Rosa et al. } \\
2005[44]\end{array}$ & Italy & $\begin{array}{l}\text { Retrospective } \\
\text { cohort study }\end{array}$ & 374 & 60 & $42^{b}$ & $\begin{array}{l}\text { Prevalence of trauma- } \\
\text { related anal fistula } \\
\text { (iatrogenic) }\end{array}$ \\
\hline & $\begin{array}{l}\text { Sultan et al. } \\
2010[45]\end{array}$ & France & $\begin{array}{l}\text { Prospective } \\
\text { study }\end{array}$ & 150 & 81 & 50 & $\begin{array}{l}\text { Prevalence of trauma- } \\
\text { related anal fistula } \\
\text { (iatrogenic) }\end{array}$ \\
\hline & $\begin{array}{l}\text { Bouchard } \\
\text { et al. } 2013 \\
\text { [46] }\end{array}$ & France & $\begin{array}{l}\text { Prospective } \\
\text { study }\end{array}$ & 633 & 43 & $48^{b}$ & $\begin{array}{l}\text { Prevalence of trauma- } \\
\text { related anal fistula } \\
\text { (iatrogenic) }\end{array}$ \\
\hline & $\begin{array}{l}\text { Bjelanovic } \\
\text { et al. } 2016 \\
{[47]}\end{array}$ & Spain & $\begin{array}{l}\text { Prospective } \\
\text { observational } \\
\text { study }\end{array}$ & 402 & 67 & 46 & $\begin{array}{l}\text { Prevalence of trauma- } \\
\text { related anal fistula } \\
\text { (iatrogenic) }\end{array}$ \\
\hline & $\begin{array}{l}\text { Milito et al. } \\
2017[48]\end{array}$ & Italy & $\begin{array}{l}\text { Retrospective } \\
\text { cohort study }\end{array}$ & 1000 & NR & $19-80^{\mathrm{d}}$ & $\begin{array}{l}\text { Prevalence of trauma- } \\
\text { related anal fistula } \\
\text { (iatrogenic) }\end{array}$ \\
\hline
\end{tabular}


Table 1 continued

\begin{tabular}{|c|c|c|c|c|c|c|c|}
\hline Etiology & Study & Region & Design & $\begin{array}{l}\text { Number } \\
\text { of } \\
\text { patients } \\
\text { included }\end{array}$ & $\begin{array}{l}\text { Male } \\
(\%)\end{array}$ & $\begin{array}{l}\text { Average } \\
\text { age } \\
\text { (years) }\end{array}$ & $\begin{array}{l}\text { Estimation made from } \\
\text { the reported data }\end{array}$ \\
\hline \multirow[t]{3}{*}{$\begin{array}{l}\text { Systemic } \\
\text { infection }\end{array}$} & $\begin{array}{l}\text { Scieux et al. } \\
1989[49]\end{array}$ & France & Case series & 27 & 100 & $17-73^{\mathrm{d}}$ & $\begin{array}{l}\text { Prevalence of infection- } \\
\text { related anal fistula } \\
\text { (lymphogranuloma } \\
\text { venereum) }\end{array}$ \\
\hline & $\begin{array}{l}\text { Alvarez } \\
\text { Conde } \\
\text { et al. } 1992 \\
\text { [50] }\end{array}$ & Spain & $\begin{array}{l}\text { Cases report } \\
\text { and review }\end{array}$ & NA & NA & NA & $\begin{array}{l}\text { Prevalence of infection- } \\
\text { related anal fistula } \\
\text { (tuberculosis) }\end{array}$ \\
\hline & $\begin{array}{r}\text { Gupta et al. } \\
2005[51]\end{array}$ & NR & Review & NA & NA & NA & $\begin{array}{l}\text { Prevalence of infection- } \\
\text { related anal fistula } \\
\text { (tuberculosis) }\end{array}$ \\
\hline Cancer & $\begin{array}{r}\text { Jensen et al. } \\
1988 \text { [52] }\end{array}$ & Denmark & Case series & 21 & 38 & $70^{\mathrm{b}}$ & $\begin{array}{l}\text { Prevalence of } \\
\text { adenocarcinoma- } \\
\text { related anal fistula }\end{array}$ \\
\hline Congenital & $\begin{array}{l}\text { Cuschieri } \\
2001[53]\end{array}$ & Europe & $\begin{array}{l}\text { Epidemiologic } \\
\text { registry survey }\end{array}$ & $4.6 \mathrm{M}$ & NR & Newborns & $\begin{array}{l}\text { Prevalence of } \\
\text { congenital anal fistula }\end{array}$ \\
\hline \multicolumn{8}{|c|}{$\begin{array}{l}M \text { million, } N A \text { not applicable, } N R \text { not reported, SEESG-CD Spanish Epidemiological and Economic Study Group on } \\
\text { Crohn's disease }\end{array}$} \\
\hline
\end{tabular}

Prevention and Control, the prevalence of tuberculosis in Europe is $1.65 / 10,000$ population [57]. Alvarez Conde et al. [50] reported that $0.7 \%$ of patients with tuberculosis have perianal involvement, which corresponds to a prevalence of $0.012 / 10,000$ population in Europe. Among these patients, anal fistulas were the most common presentation, occurring in 80-91\% [51], suggesting a prevalence of tuberculosis-related anal fistulas of 0.009-0.011 per 10,000 population, with a median of $0.1 /$ 10,000 . In a case series of 27 patients with lymphogranuloma venereum, Scieux et al. [49] observed two cases of anal fistulas (7.4\%). Based on the reported prevalence of 0.08 cases of lymphogranuloma venereum/10,000 in Europe [58], the estimated prevalence of anal fistulas related to lymphogranuloma venereum was $0.006 / 10,000$ population. Combined with the estimated prevalence of tuberculosis-related fistulas, these data indicate a prevalence of anal fistulas related to infection of $0.016 / 10,000$ population.

A single article reporting data on anal fistulas in patients with anal adenocarcinoma met the criteria for inclusion. In a case series of 21 patients with anal adenocarcinoma, Jensen et al. [52] reported that anal fistulas occurred in $23.8 \%$. Assuming a prevalence of 0.11 cases of anal adenocarcinoma/10,000 population in 
Table 2 Prevalence rates of anal fistulas among patients with Crohn's disease, derived from European studies

\begin{tabular}{|c|c|c|c|c|}
\hline Study & Design & Cohort source & $\begin{array}{l}\text { Number of } \\
\text { patients } \\
\text { included }\end{array}$ & $\begin{array}{l}\text { Prevalence } \\
(\%)\end{array}$ \\
\hline $\begin{array}{r}\text { SEESG-CD } \\
1999[39]\end{array}$ & $\begin{array}{l}\text { Cross-sectional } \\
\text { observation study }\end{array}$ & 39 hospitals throughout Spain & 635 & 6.0 \\
\hline $\begin{array}{l}\text { Chaparro et al. } \\
2011[40]\end{array}$ & $\begin{array}{l}\text { Population-based } \\
\text { cohort study }\end{array}$ & 11 hospitals in Madrid & 2391 & 4.32 \\
\hline $\begin{array}{l}\text { Göttgens et al. } \\
2017 \text { [41] }\end{array}$ & $\begin{array}{l}\text { Population-based } \\
\text { cohort study }\end{array}$ & $\begin{array}{l}\text { Population-based IBD cohort in the } \\
\text { Netherlands (IBD South Limburg registry) }\end{array}$ & 1162 & 4.49 \\
\hline $\begin{array}{l}\text { Georgiadou } \\
\text { et al. } 2019 \\
\text { [42] }\end{array}$ & $\begin{array}{l}\text { Cross-sectional claims } \\
\text { database analysis }\end{array}$ & $\begin{array}{l}\text { Claims data from several German company } \\
\text { health insurance funds }\end{array}$ & 13,346 & 3.38 \\
\hline Total $^{\mathrm{a}}$ & & & & 4.55 \\
\hline
\end{tabular}

IBD inflammatory bowel disease, SEESG-CD Spanish Epidemiological and Economic Study Group on Crohn's disease ${ }^{a}$ Weighted average

Europe [59], this corresponds to a prevalence of anal adenocarcinoma-related fistulas of $0.026 /$ 10,000 population. Considering that a proportion of anal adenocarcinoma-related fistulas occur in patients with $\mathrm{CD}$, the prevalence of these fistulas in the non-CD population has been calculated by subtracting the mean estimated prevalence of fistula-related anal cancers in $\mathrm{CD}$ in Europe based on published data $(0.006 / 10,000$ population) [60-62], resulting in an estimated prevalence of $0.02 / 10,000$ population.

The literature searches retrieved one suitable article on congenital anal fistulas. In a 2001 European epidemiologic study, Cuschieri et al. [53] reported a prevalence of 1.04 congenital anal fistulas/10,000 live births. Extrapolation of the estimate to the European Union population using the most recent data for the annual number of live births (5.1 million) [63] and the total population (508.5 million) [63] resulted in an estimated prevalence of $0.01 / 10,000$ population.

\section{Overall Prevalence of Anal Fistulas in Europe}

The overall prevalence of anal fistulas in Europe, estimated as the sum of the estimated prevalence for all etiologies, was 1.69/10,000 population (Table 5). CD and cryptoglandular infection were the predominant etiologies, accounting for more than $95 \%$ of all cases. In comparison, the overall incidence of anal fistulas in Europe was 1.15/10,000 population.

\section{Population-Based Database Analysis}

The results of the population-based database analysis are summarized in Table 6 . Comparison of data from the UK THIN database with the European population yielded a standardized prevalence of 1.83 anal fistulas/10,000 population (95\% confidence interval 1.68-1.98) in 2017 , with a range of $1.83-2.36 / 10,000$ population during the 4-year study period. The close agreement between the estimates derived from the THIN database and the systematic literature reviews confirms the robustness of the literature-based estimate.

\section{DISCUSSION}

The present study represents the first systematic literature reviews and corroborative analysis of a large, population-based database to ascertain the prevalence of anal fistulas in Europe. The 


\section{EUROPE}

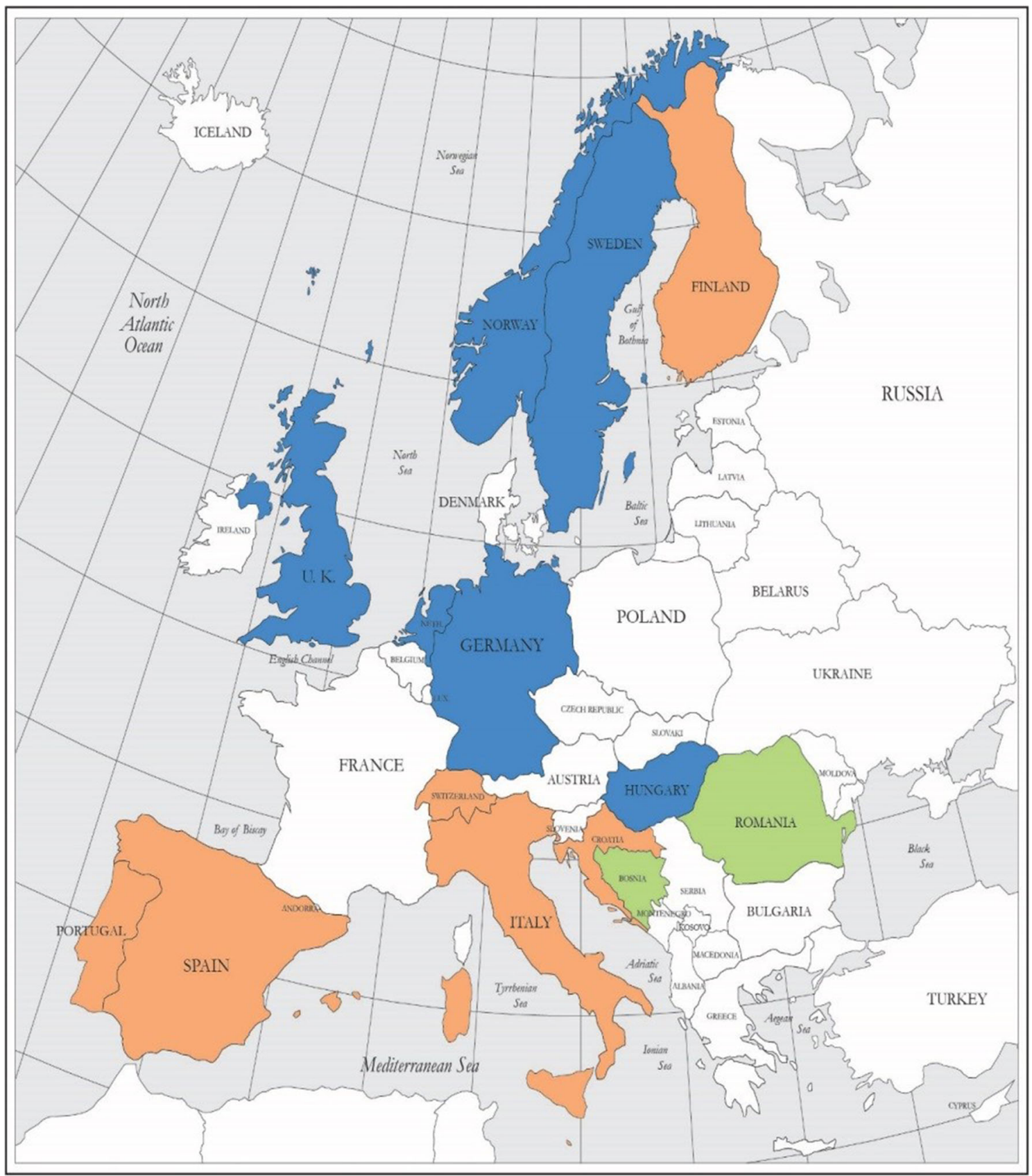

\section{Crohn's disease prevalence}

per 10,000 reported in papers published between 2008 and 2017

प Unknown (or country not part of European Union)

$>15$

$5-15$

$<5$ 
4Fig. 2 Reported prevalence of Crohn's disease in Europe by country published over the last 10 years (2008-2017). Rates are per 10,000 population

findings suggest that the prevalence of anal fistulas is $1.69 / 10,000$ population, with an annual incidence of $1.15 / 10,000$ population. According to the threshold definition of 5/10,000 population established by the European Medicines Agency, the estimated prevalence of anal fistulas meets the criteria for a rare condition [64].

A substantial majority of prevalent cases of anal fistulas were either of cryptoglandular origin or secondary to CD (more than 95\%); a variety of etiologies, including infection, trauma, cancer, and congenital malformation, account for the remaining 5\%. While anal fistulas have occasionally been reported in patients with certain infections, diabetes, ulcerative colitis, and diverticulitis, such cases are extremely rare. In terms of incidence, cryptoglandular fistulas were clearly predominant compared with CD-related fistulas $(75 \%$ vs $18 \%)$, whereas prevalence rates were relatively
Table 4 Estimated prevalence rates of anal fistulas related to etiologies other than Crohn's disease and cryptoglandular infection

\begin{tabular}{ll}
\hline Etiology & Prevalence (per 10,000 population) \\
\hline Infection & 0.016 \\
Trauma & 0.031 \\
Cancer & 0.02 \\
Congenital & 0.01 \\
Total & 0.078 \\
\hline
\end{tabular}

balanced (51\% vs $45 \%$ ). Such differences were driven by the longer duration and high-level relapse of anal fistulas in CD.

The strengths of the present study include the performance of two separate literature reviews by independent reviewers and use of a large population-based database as a validation dataset. Population-based data sources are considered the gold standard for epidemiologic analyses. In the present analysis, prevalence estimates from population-based data sources were adjusted to account for differences in the duration of anal fistulas according to etiology,

Table 3 Prevalence rates of anal fistulas among patients undergoing hemorrhoidectomy, derived from European studies

\begin{tabular}{|c|c|c|c|c|}
\hline Study & Design & Cohort source & $\begin{array}{l}\text { Number of patients } \\
\text { included }\end{array}$ & $\begin{array}{l}\text { Prevalence } \\
(\%)\end{array}$ \\
\hline $\begin{array}{l}\text { Sielezneff et al. } \\
1997 \text { [43] }\end{array}$ & $\begin{array}{l}\text { Retrospective cohort } \\
\text { study }\end{array}$ & A French hospital (1975-1990) & 1134 & 1.2 \\
\hline $\begin{array}{l}\text { Rosa et al. } 2005 \\
{[44]}\end{array}$ & $\begin{array}{l}\text { Retrospective cohort } \\
\text { study }\end{array}$ & A UK hospital (1983-2002) & 374 & 0.5 \\
\hline $\begin{array}{l}\text { Sultan et al. } 2010 \\
{[45]}\end{array}$ & Prospective study & A French hospital (2001-2006) & 150 & 0.67 \\
\hline $\begin{array}{l}\text { Bouchard et al. } \\
2013 \text { [46] }\end{array}$ & Prospective study & $\begin{array}{l}\text { Multiple hospitals across France } \\
(2007-2008)\end{array}$ & 633 & 0.16 \\
\hline $\begin{array}{l}\text { Bjelanovic et al. } \\
2016 \text { [47] }\end{array}$ & $\begin{array}{l}\text { Prospective } \\
\quad \text { observational study }\end{array}$ & $\begin{array}{l}\text { A surgical center in Spain } \\
\quad(2010-2014)\end{array}$ & 402 & 1.2 \\
\hline $\begin{array}{l}\text { Milito et al. } 2017 \\
\text { [48] }\end{array}$ & $\begin{array}{l}\text { Retrospective cohort } \\
\text { study }\end{array}$ & An Italian hospital (2001-2014) & 1000 & 0.3 \\
\hline Total $^{\mathrm{a}}$ & & & & 0.69 \\
\hline
\end{tabular}

${ }^{a}$ Weighted average 
Table 5 Estimated prevalence and incidence of anal fistulas in Europe

\begin{tabular}{lllll}
\hline Etiology & $\begin{array}{l}\text { Prevalence (per 10,000 } \\
\text { population) }\end{array}$ & $\begin{array}{l}\text { Proportion of } \\
\text { prevalent cases (\%) }\end{array}$ & $\begin{array}{l}\text { Incidence (per 10,000 } \\
\text { population) }\end{array}$ & $\begin{array}{l}\text { Proportion of } \\
\text { incident cases (\%) }\end{array}$ \\
\hline Cryptoglandular & 0.86 & 50.8 & 0.86 & 74.9 \\
Crohn's disease & 0.76 & 44.6 & 0.21 & 18.3 \\
Other $^{\mathrm{a}}$ & 0.078 & 4.6 & 0.078 & 6.8 \\
Total & 1.69 & 100.0 & 1.15 & 100.0 \\
\hline
\end{tabular}

a Includes infections, trauma, anal adenocarcinoma, and congenital malformation

Table 6 Prevalence of anal fistulas based on analysis of data from the UK THIN database

\begin{tabular}{lllll}
\hline & $\mathbf{2 0 1 7}$ & $\mathbf{2 0 1 6}$ & $\mathbf{2 0 1 5}$ & $\mathbf{2 0 1 4}$ \\
\hline Active patients, $n$ & $3,172,922$ & $3,569,535$ & $4,219,577$ & $4,875,428$ \\
Patients with anal fistula, $n^{\mathrm{a}}$ & 579 & 688 & 938 & 1143 \\
Total per 10,000 population & 1.82 & 1.93 & 2.22 & 2.34 \\
UK standardized estimate per 10,000 population & 1.80 & 1.89 & 2.19 & 2.31 \\
$\quad(95 \% \text { CI })^{\mathrm{b}}$ & $(1.65-1.94)$ & $(1.75-2.03)$ & $(2.05-2.33)$ & $(2.18-2.44)$ \\
EU standardized estimate per 10,000 population (95\% & 1.83 & 1.94 & 2.23 & 2.36 \\
CI) & $(1.68-1.98)$ & $(1.79-2.08)$ & $(2.08-2.37)$ & $(2.22-2.50)$ \\
\hline
\end{tabular}

Mid-year point prevalence calculated on the basis on the number of prevalent cases of anal fistula as of July 1 each year and the number of active patients on July 1 of the corresponding year

$C I$ confidence interval

${ }^{a}$ Includes anal fistulas within the previous 12 months in patients without Crohn's disease and anal fistulas within the previous 4 years in patients with Crohn's disease

b Stratified by age and sex, and standardized to the UK population based on 2016 census data [33]

c Stratified by age and sex, and standardized to the EU populations based on 2013 population estimates [34]

and results from the database were stratified by age and sex to facilitate extrapolation to the European population. Importantly, the close agreement between the estimates derived from the literature reviews and population-based database analysis provided compelling corroborative evidence to support the robustness of the findings.

The present findings should be interpreted in the context of certain limitations, including the limited number of studies with suitable data to support estimation of the prevalence of certain etiologies of anal fistulas, and the low number of patients included in some studies. Given the scarcity of epidemiological data, the authors assumed that the identified papers from the first literature search would be significantly heterogeneous, not only in terms of study design and reported epidemiology outcomes but also in terms of quality. As such, a formal comparative assessment of quality/bias was not conducted. For the second literature search, the risk of bias in the identified studies was assessed and, as expected, wide heterogeneity (percentages of items at high risk of bias in the different studies ranged from 0 to $60 \%$ ) was reported. As such, heterogeneity in the risk of bias between studies is a limitation of this study. Additionally, it should be considered that the average duration of anal fistulas in CD used to estimate the prevalence of this fistula etiology comes from a study conducted in the pre-biologic era, and thus it cannot be ruled out that the average duration has changed. Finally, the analysis of 
data from the population-based primary care database was subject to potential bias due to misclassification or underreporting of diagnoses and procedures.

\section{CONCLUSIONS}

It was estimated from the published literature that the prevalence of anal fistulas in Europe is $1.69 / 10,000$ population. The robustness of this estimate was confirmed by analysis of data from a population-based database $(1.83 / 10,000$ population).

\section{ACKNOWLEDGEMENTS}

Funding. This study was funded by Takeda Pharmaceutical U.S.A., Inc. and TiGenix SAU. The systematic literature review and THIN database analysis were funded by Takeda Pharmaceuticals U.S.A., Inc. Takeda Pharmaceutical U.S.A., Inc. also funded the Rapid Service and Open Access Fees of Advances in Therapy. All authors had full access to all of the data in this study and take complete responsibility for the integrity of the data and accuracy of the data analysis.

Editorial Assistance. Editorial assistance in the preparation of this manuscript was provided by Ken Glasscock and Geoff Marx of BioScience Communications, New York. Support for this assistance was funded by TiGenix SAU.

Authorship. All named authors meet the International Committee of Medical Journal Editors (ICMJE) criteria for authorship for this article, take responsibility for the integrity of the work as a whole, and have given their approval for this version to be published.

Authorship Contributions. All authors analyzed and interpreted the data, contributed to the writing of the manuscript, and approved the final version of the manuscript. Javaria Mona Khalid, Marc van Dijk, Dimitri Bennett, and Suvi RK Hokkanen conducted The Health
Improvement Network database analysis. Mary Carmen Diez and Javaria Mona Khalid secured the funding.

Prior Presentation. An abstract based on a summary of the contents of this manuscript was submitted and accepted for a poster presentation at the 13th Meeting of the European Society of Coloproctology (September 26-28, 2018, Nice, France).

Disclosures. Damián García-Olmo has received personal fees from Takeda and TiGenix; and has a patent and a patent pending. Gert Van Assche has received personal fees from TiGenix; and grants and personal fees from AbbVie, Ferring, Genentech-Roche, Janssen, MSD, Pfizer, and Takeda. Ignacio Tagarro was a TiGenix employee at the time the study was conducted and is now a Takeda employee. Mary Carmen Diez is a TiGenix employee. Marie Paule Richard is a TiGenix employee. Javaria Mona Khalid was a Takeda employee at the time the study was conducted. Marc van Dijk was a Takeda employee at the time the study was conducted. Dimitri Bennett is a Takeda employee. Suvi RK Hokkanen is employed by IQVIA. Julián Panés has received personal fees from Takeda, TiGenix, AbbVie, Boehringer Ingelheim, Celgene, Galapagos, GenentechRoche, GSK, Janssen, MSD, Novartis, Oppilan, Pfizer, Theravance, and Vivelix.

Compliance with Ethics Guidelines. The literature review in this article is based on previously conducted studies and does not contain any studies with human participants or animals performed by any of the authors. The population-based database analysis was reviewed and approved by the THIN Scientific Review Committee (SRC 18THINO06). The study conformed to the Helsinki Declaration of 1964, as revised in 2013, and Springer's ethical policy.

Data Availability. The dataset generated during and/or analyzed during the current study is not publicly available due to copyright issues but is available from the corresponding author on reasonable request. 
Open Access. This article is distributed under the terms of the Creative Commons Attribution-NonCommercial 4.0 International License (http://creativecommons.org/licenses/ by-nc/4.0/), which permits any noncommercial use, distribution, and reproduction in any medium, provided you give appropriate credit to the original author(s) and the source, provide a link to the Creative Commons license, and indicate if changes were made.

\section{REFERENCES}

1. Hvas CL, Dahlerup JF, Jacobsen BA, et al. Diagnosis and treatment of fistulising Crohn's disease. Dan Med Bull. 2011;58:C4338.

2. Siegmund B, Feakins RM, Barmias G, et al. Results of the fifth scientific workshop of the ECCO (II): pathophysiology of perianal fistulizing disease. J Crohns Colitis. 2016;10:377-86.

3. Pickhardt PJ, Bhalla S, Balfe DM. Acquired gastrointestinal fistulas: classification, etiologies, and imaging evaluation. Radiology. 2002;224:9-23.

4. Kiehne K, Fincke A, Brunke G, Lange T, Folsch UR, Herzig KH. Antimicrobial peptides in chronic anal fistula epithelium. Scand J Gastroenterol. 2007;42:1063-9.

5. Rakinic J, Poola VP. Hemorrhoids and fistulas: new solutions to old problems. Curr Probl Surg. 2014;51:98-137.

6. Sugrue J, Nordenstam J, Abcarian H, et al. Pathogenesis and persistence of cryptoglandular anal fistula: a systematic review. Tech Coloproctol. 2017;21:425-32.

7. Vogel JD, Johnson EK, Morris AM, et al. Clinical practice guideline for the management of anorectal abscess, fistula-in-ano, and rectovaginal fistula. Dis Colon Rectum. 2016;59:1117-33.

8. Parks AG. Pathogenesis and treatment of fistuila-inano. Br Med J. 1961;1:463-9.

9. Scharl M, Rogler G. Pathophysiology of fistula formation in Crohn's disease. World J Gastrointest Pathophysiol. 2014;5:205-12.

10. Nielsen $\mathrm{OH}$, Rogler G, Hahnloser D, Thomsen OO. Diagnosis and management of fistulizing Crohn's disease. Nat Clin Pract Gastroenterol Hepatol. 2009;6:92-106.
11. Gordis L. The occurrence of disease: I. Disease surveillance and measures of morbidity. Epidemiology. 5th ed. Philadelphia: Saunders; 2013. p. 38-60.

12. Pavlovic-Calic N, Salkic NN, Gegic A, Smajic M, Alibegovic E. Crohn's disease in Tuzla region of Bosnia and Herzegovina: a 12-year study (1995-2006). Int J Colorectal Dis. 2008;23:957-64.

13. Klarin I, Majnaric L, Jovanovic Z, Nakic D, Vcev I, Vcev A. Epidemiology and clinical presentation of inflammatory bowel disease in Zadar County, Croatia. Coll Antropol. 2013;37:1161-70.

14. Pezerovic D, Klarin I, Zulj M, Majnaric L, Khaznadar $\mathrm{E}, \mathrm{Vcev}$ A. Incidence and prevalence of inflammatory bowel disease in Vukovarsko-Srijemska County, Croatia, 1991-2000 and 2001-2010: a population-based study. Coll Antropol. 2014;38:115-23.

15. Manninen $\mathrm{P}$, Karvonen AL, Huhtala H, Rasmussen M, Collin P. The epidemiology of inflammatory bowel diseases in Finland. Scand J Gastroenterol. 2010;45:1063-7.

16. Hein R, Koster I, Bollschweiler E, Schubert I. Prevalence of inflammatory bowel disease: estimates for 2010 and trends in Germany from a large insurance-based regional cohort. Scand J Gastroenterol. 2014;49:1325-35.

17. Lakatos L, Kiss LS, David G, et al. Incidence, disease phenotype at diagnosis, and early disease course in inflammatory bowel diseases in Western Hungary, 2002-2006. Inflamm Bowel Dis. 2011;17:2558-65.

18. Kurti Z, Vegh Z, Golovics PA, et al. Nationwide prevalence and drug treatment practices of inflammatory bowel diseases in Hungary: a populationbased study based on the National Health Insurance Fund database. Dig Liver Dis. 2016;48:1302-7.

19. Di Domenicantonio R, Cappai G, Arca M, et al. Occurrence of inflammatory bowel disease in central Italy: a study based on health information systems. Dig Liver Dis. 2014;46:777-82.

20. Galeone C, Pelucchi C, Barbera G, Citterio C, La Vecchia C, Franchi A. Crohn's disease in Italy: a critical review of the literature using different data sources. Dig Liver Dis. 2017;49:459-66.

21. Valpiani D, Manzi I, Mercuriali M, et al. A model of an inflammatory bowel disease population-based registry: the Forli experience (1993-2013). Dig Liver Dis. 2018;50:32-6.

22. de Groof EJ, Rossen NG, van Rhijn BD, et al. Burden of disease and increasing prevalence of inflammatory bowel disease in a population-based cohort in 
the Netherlands. Eur J Gastroenterol Hepatol. 2016;28:1065-72.

23. van den Heuvel TRA, Jeuring SFG, Zeegers MP, et al. A 20-year temporal change analysis in incidence, presenting phenotype and mortality, in the Dutch IBDSL cohort-can diagnostic factors explain the increase in IBD incidence? J Crohns Colitis. 2017;11:1169-79.

24. Bengtson MB, Solberg C, Aamodt G, et al. Familial aggregation in Crohn's disease and ulcerative colitis in a Norwegian population-based cohort followed for 10 years. J Crohns Colitis. 2009;3:92-9.

25. Azevedo LF, Magro F, Portela F, et al. Estimating the prevalence of inflammatory bowel disease in Portugal using a pharmaco-epidemiological approach. Pharmacoepidemiol Drug Saf. 2010;19:499-510.

26. Mocanu D, Catuneanu AM, Diculescu M, Gologan S, Sporea I. Current epidemiologic trends in Crohn's disease: data from a tertiary referral centre in Bucharest: (Fundeni Institute, Center of Gastroenterology and Hepatology). Maedica (Buchar). 2010;5:95-101.

27. Lucendo AJ, Hervias D, Roncero O, et al. Epidemiology and temporal trends (2000-2012) of inflammatory bowel disease in adult patients in a central region of Spain. Eur J Gastroenterol Hepatol. 2014;26:1399-407.

28. Carpio D, Barreiro-de Acosta M, Echarri A, et al. Influence of urban/rural and coastal/inland environment on the prevalence, phenotype, and clinical course of inflammatory bowel disease patients from northwest of Spain: a cross-sectional study. Eur J Gastroenterol Hepatol. 2015;27:1030-7.

29. Büsch K, Ludvigsson JF, Ekstrom-Smedby K, Ekbom A, Askling J, Neovius M. Nationwide prevalence of inflammatory bowel disease in Sweden: a population-based register study. Aliment Pharmacol Ther. 2014;39:57-68.

30. Juillerat P, Pittet V, Bulliard JL, et al. Prevalence of inflammatory bowel disease in the canton of Vaud (Switzerland): a population-based cohort study. J Crohns Colitis. 2008;2:131-41.

31. Steed H, Walsh S, Reynolds N. Crohn's disease incidence in NHS Tayside. Scott Med J. 2010;55:22-5.

32. Population Reference Bureau. 2017. 2017 world population data sheet. https://assets.prb.org/pdf17/ 2017_World_Population.pdf. Accessed Aug 2019.

33. Liberati A, Altman DG, Tetzlaff J, et al. The PRISMA statement for reporting systematic reviews and meta-analyses of studies that evaluate healthcare interventions: explanation and elaboration. BMJ. 2009;339:b2700.

34. The Health Improvement Network (THIN) Database Research Group. 2019. http://www.ucl.ac. uk/epidemiology-health-care/node/7035/database. Accessed Oct 2019.

35. Bell SJ, Williams AB, Wiesel P, Wilkinson K, Cohen RC, Kamm MA. The clinical course of fistulating Crohn's disease. Aliment Pharmacol Ther. 2003;17:1145-51.

36. Office for National Statistics. Dataset: estimates of the population for the UK, England and Wales, Scotland and Northern Ireland. 2019. https:// www.ons.gov.uk/peoplepopulationandcommunity/ populationandmigration/populationestimates/data sets/populationestimatesforukenglandandwalesscot landandnorthernireland. Accessed Aug 2019.

37. European Commission. Revision of the European Standard Population-report of Eurostat's task force: 2013 edition. 2013. http://ec.europa.eu/ eurostat/documents/3859598/5926869/KS-RA-13028-EN.PDF/e713fa79-1add-44e8-b23d-5e8fa09b3 f8f. Accessed Aug 2019.

38. Sainio P. Fistula-in-ano in a defined population. Incidence and epidemiological aspects. Ann Chir Gynaecol. 1984;73:219-24.

39. Spanish Epidemiological and Economic Study Group on Crohn's Disease. Epidemiological and clinical features of Spanish patients with Crohn's disease. Spanish Epidemiological and Economic Study Group on Crohn's disease. Eur J Gastroenterol Hepatol. 1999;11:1121-7.

40. Chaparro M, Burgueno P, Vera I, et al. Epidemiological study of perianal fistulas in patients with Crohn's disease. Gastroenterology. 2011;140:S-736.

41. Göttgens KW, Jeuring SF, Sturkenboom R, et al. Time trends in the epidemiology and outcome of perianal fistulizing Crohn's disease in a populationbased cohort. Eur J Gastroenterol Hepatol. 2017;29:595-601.

42. Georgiadou E, Fanter L, Brandes A, Ratsch BA, Friedel H, Dignass A. Perianal fistulas in adult patients with Crohn's disease in Germany-a retrospective cross-sectional analysis of claims data from German sickness funds. Z Gastroenterol. 2019;57:574-83.

43. Sielezneff I, Salle E, Lecuyer J, Brunet C, Sarles JC, Sastre B. Early postoperative morbidity after hemorrhoidectomy using the Milligan-Morgan technic. A retrospective studies of 1134 cases. J Chir (Paris). 1997;134:243-7. 
44. Rosa G, Lolli P, Piccinelli D, et al. Submucosal reconstructive hemorrhoidectomy (Parks' operation): a 20-year experience. Tech Coloproctol. 2005;9:209-14.

45. Sultan S, Rabahi N, Etienney I, Atienza P. Stapled haemorrhoidopexy: 6 years' experience of a referral centre. Colorectal Dis. 2010;12:921-6.

46. Bouchard D, Abramowitz L, Castinel A, et al. Oneyear outcome of haemorrhoidectomy: a prospective multicentre French study. Colorectal Dis. 2013;15:719-26.

47. Bjelanovic Z, Draskovic M, Veljovic M, Lekovic I, Karanikolas M, Stamenkovic D. Transanal hemorrhoid dearterialization is a safe and effective outpatient procedure for the treatment of hemorrhoidal disease. Cir Esp. 2016;94:588-94.

48. Milito G, Lisi G, Aronadio E, et al. Ligasure ${ }^{\mathrm{TM}}$ hemorrhoidectomy: how we do. Minerva Gastroenterol Dietol. 2017;63:44-9.

49. Scieux C, Barnes R, Bianchi A, Casin I, Morel P, Perol Y. Lymphogranuloma venereum: 27 cases in Paris. J Infect Dis. 1989;160:662-8.

50. Alvarez Conde JL, Gutierrez Alonso VM, Del Riego Tomas J, Garcia Martinez I, Arizcun Sanchez-Morate A, Vaquero Puerta C. Perianal ulcers of tubercular origin. A report of three new cases. Rev Esp Enferm Dig. 1992;81:46-8.

51. Gupta PJ. Ano-perianal tuberculosis-solving a clinical dilemma. Afr Health Sci. 2005;5:345-7.

52. Jensen SL, Shokouh-Amiri MH, Hagen K, Harling H, Nielsen OV. Adenocarcinoma of the anal ducts. A series of 21 cases. Dis Colon Rectum. 1988;31:268-72.

53. Cuschieri A. Descriptive epidemiology of isolated anal anomalies: a survey of 4.6 million births in Europe. Am J Med Genet. 2001;103:207-15.

54. Eglinton TW, Barclay ML, Gearry RB, Frizelle FA. The spectrum of perianal Crohn's disease in a population-based cohort. Dis Colon Rectum. 2012;55:773-7.

55. Herold A, Joos A, Bussen D. Operations for hemorrhoids: indications and techniques. Chirurg. 2012;83:1040-8.
56. Brown S, Tiernan J, Biggs K, et al. The HubBLe Trial: haemorrhoidal artery ligation (HAL) versus rubber band ligation (RBL) for symptomatic second- and third-degree haemorrhoids: a multicentre randomised controlled trial and health-economic evaluation. Health Technol Assess. 2016;20:1-150.

57. European Centre for Disease Prevention and Control, WHO Regional Office for Europe. Tuberculosis surveillance and monitoring in Europe. 2016. https://ecdc.europa.eu/sites/portal/files/media/en/ publications/Publications/ecdc-tuberculosis-survei llance-monitoring-Europe-2016.pdf. Accessed Aug 2019.

58. Stary G, Stary A. Lymphogranuloma venereum outbreak in Europe. J Dtsch Dermatol Ges. 2008;6: 935-40.

59. RARECARENet. Information Network on Rare Cancers. 2008. http://www.rarecarenet.eu/rarecare net/images/indicators/Observed\%2015\%20year\%20 prevalence.pdf. Accessed Aug 2019.

60. Baars JE, Kuipers EJ, Dijkstra G, et al. Malignant transformation of perianal and enterocutaneous fistulas is rare: results of 17 years of follow-up from the Netherlands. Scand J Gastroenterol. 2011;46:319-25.

61. Beaugerie L, Carrat F, Nahon S, et al. High risk of anal and rectal cancer in patients with anal and/or perianal Crohn's disease. Clin Gastroenterol Hepatol. 2018;16(892-9):e2.

62. Wisniewski A, Flejou JF, Siproudhis L, Abramowitz L, Svrcek M, Beaugerie L. Anal neoplasia in inflammatory bowel disease: classification proposal, epidemiology, carcinogenesis, and risk management perspectives. J Crohns Colitis. 2017;11:1011-8.

63. European Commission. Eurostat Database. 2018. http://ec.europa.eu/eurostat/data/database. Accessed Aug 2019.

64. European Medicines Agency, Committee for Orphan Medicinal Products. Alofisel-Orphan Maintenance Assessment Report. 2018. https://www.ema.europa. eu/en/documents/orphan-maintenance-report/ alofisel-orphan-maintenance-assessment-reportinitial-authorisation_en.pdf. Accessed Oct 2019. 